\title{
PENGARUH GAYA HIDUP DAN CITRA MEREK TERHADAP PENGAMBILAN KEPUTUSAN PELANGGAN
}

\author{
Abdul Rahmat \\ Universitas Negeri Gorontalo \\ abdulrahmat@ung.ac.id
}

\begin{abstract}
The development of cosmetics industry in Indonesia is currently in good condition. People, especially women, are increasingly aware of the importance of cosmetics ranging from the use for important events to as daily necessities. The roles of lifestyle through activity, interest, and opinion play a major role in determining a person's decision especially in terms of making a purchase (Sathis and Rajamohan, 2008). Other than lifestyle brand image play and important role in customer buying decision of lipstick. Path analysis are conducted in order to determine the impact of both factor on buying decision.Furthermore, the method analyze the causal relationships that occur in multiple regression analysts if the independent variables affect other variables either partially or simultaneously.Results show the significance of the model which show that both lifestyle and brand image gave impact on lipstick buying decisionby $75.6 \%$ and $24.4 \%$ are influenced by other variables not explained in the research. All in all it become more concise to say that lifestyle and brand image are take depth root in customer decision making processes.
\end{abstract}

Key Words: Brand Image, Lifestyle, Buying Decision, Cosmetics

\begin{abstract}
Abstrak: Perkembangan industri kosmetik di Indonesia saat ini dalam kondisi baik. Orang-orang, terutama wanita, semakin sadar akan pentingnya kosmetik mulai dari penggunaan untuk acara penting hingga kebutuhan sehari-hari. Peran gaya hidup melalui aktivitas, minat, dan opini memainkan peran utama dalam menentukan keputusan seseorang terutama dalam hal melakukan pembelian (Sathis dan Rajamohan, 2008). Citra merek dan gaya hidup sangat berperan penting dalam keputusan pembelian konsumen lipstik. Analisis jalur dilakukan untuk mengetahui dampak kedua faktor terhadap keputusan pembelian. Selanjutnya, metode analisis hubungan kausal yang terjadi pada banyak analis regresi jika variabel independen mempengaruhi variabel lain baik secara parsial maupun simultan. Hasil menunjukkan signifikansi model. yang menunjukkan bahwa baik gaya hidup maupun citra merek memberi dampak pada keputusan pembelian lipstik sebesar 75,6\% dan $24,4 \%$ dipengaruhi oleh variabel lain yang tidak dijelaskan dalam penelitian. Semua dalam semua itu menjadi lebih ringkas untuk mengatakan bahwa gaya hidup dan citra merek mengambil akar mendalam dalam proses pengambilan keputusan pelanggan.
\end{abstract}

Kata Kunci: Citra Merek, Gaya Hidup, Keputusan Pembelian, Kosmetik

\section{PENDAHULUAN}

Perkembangan industri kosmetik di Indonesia saat ini tergolong sangatlah baik. Masyarakat terutama kaum wanita, semakin sadar akan pentingnya kosmetik mulai dari pengunaan untuk event-event penting hingga sebagai kebutuhan sehari-hari. Tren penggunaan kosmetik yang semakin berkembang, serta tuntutan seseorang untuk berpenampilan menarik di depan khalayak umum menjadi salah satu alasan industri kosmetik berkembang dengan baik di Indonesia. Menurut data Kementrian Perdagangan 
Republik Indonesia, penjualan kosmetik di Indonesia pada tahun 2012 meningkat sebesar 12\% dari tahun sebelumnya yaitu sebesar Rp 8,5 triliun menjadi Rp. 9,76 triliun dan terus mengalami peningkatan (Kemenperin, 2013).Menariknya berdasarkan data top brand award padatahun 2015 untuk kategori lipstick secara penjualan untuk kategori lipstick saat ini masih didominasi oleh produk lokal yang sejalan dengan data top brand index dari tahun 2012 - 2015 pada Tabel 1.

Tabel 1. Top Brand Index Kategori Lipstik 2012 - 2015

(Top Brand Award, 2015)

\begin{tabular}{cllllll}
\hline Tahun & \multicolumn{2}{c}{2013} & \multicolumn{2}{c}{2014} & \multicolumn{2}{c}{2015} \\
\cline { 2 - 7 } NO & Merk & TBI & MERK & TBI & MERK & TBI \\
\hline 1 & Revlon & $16,6 \%$ & WARDAH & $13,0 \%$ & WARDAH & $14,9 \%$ \\
2 & Pixi & $10,8 \%$ & REVLON & $12,6 \%$ & REVLON & $12,4 \%$ \\
3 & Viva & $8,3 \%$ & SARIAYU & $9,2 \%$ & PIXI & $11,0 \%$ \\
4 & Mirabella & $8,2 \%$ & PIXI & $9,0 \%$ & ORIFLAME & $7,7 \%$ \\
5 & Sariayu & $8,0 \%$ & VIVA & $8,2 \&$ & SARIAYU & $7,6 \%$ \\
\hline
\end{tabular}

Pentingnya lipstick bagi wanita dikemukakan pada studi yang dilakukan oleh Ogilvie dan Ryan (2011) dengan indikasi bahwa wanita menggunakan lipstick dengan cara yang signifikan untuk mengubah dan mempresentasikannya diri, menggunakannya sebagai cermin fluktuasi suasana hati dan identitas sehari-hari. Penelitian tersebut lebih lanjut menunjukan bahwa lipstick berperan sebagai sebuah gaya hidup yang pada akhirnya mengakar dan menjadi budaya pada kehidupan sehari-hari wanita di Australia barat. (Barth-Farkas, Faye; Vera, Antonio. 2016)

Gaya hidup merupakan sebuah stimuli dalam proses keputusan pembelian pelanggan terutama kaitannya dengan segmentasi produk dalam strategi pemasarn suatu perusahaan Secara tidak langsung, gaya hidup menggambarkan pola seseorang dalam beraksi dan berinteraksi di dunia melalui aktivitas, minat, dan lingkungannya (Kotler, 2012). Hal ini berkorelasi dengan riset yang dilakukan Hoeffler dan Keller. (2003) yang berjudul "The Marketing Advantage of Strong Brands" kekuatan merek berpengaruh besar terhadap preferensi pembelian pelanggan. Selain itu dalam penelitian ini disimpulkan bahwa perusahaan yang berinvestasi dalam pencitraan merek terhadap pelanggan memiliki daya saing yang lebih baik dibandingkan dengan perusahaan yang tidak melakukan investasi dalam pencitraan merek. (Bass, B.M. 2017).

Selain itu Sathis dan Rajamohan (2008) dalam penelitiannya yang berjudul "Consumer Behavior and Lifestyles Marketing" mengungkapkan bahwa peran gaya hidup yang diukur melalui aktivitas, minat, dan opini sangat berperan dalam menentukan keputusan seseorang terutama dalam hal melakukan pembelian. Tentu menjadi hal yang menarik untuk mengetahui sejauh apa pengaruh gaya hidup dan citra merek dalam keputusan pembelian lipstick pada benak pelanggan.

Gaya hidup seseorang dapat dilihat dari perilaku yang dilakukan oleh individu seperti kegiatan-kegiatan untuk mendapatkan atau mempergunakan barang-barang dan jasa, termasuk didalamnya proses pengambilan keputusan pada penentuan kegiatankegiatan tersebut. Lebih lanjut Amirullah (2012) menyatakan bahwa faktor-faktor yang mempengaruhi gaya hidup seseorang ada 2 faktor yaitu faktor yang berasal dari dalam diri individu (internal) dan faktor yang berasal dari luar (eksternal). 
Faktor internal yaitu sikap, pengalaman, dan pengamatan, kepribadian, konsep diri, motif, dan persepsi dengan penjelasannya sebagai berikut:

1. Sikap. Sikap berarti suatu keadaan jiwa dan keadaan pikir yang dipersiapkan untuk memberikan tanggapan terhadap suatu objek yang diorganisasi melalui pengalaman dan mempengaruhi secara langsung pada perilaku. Keadaan jiwa tersebut sangat dipengaruhi oleh tradisi, kebiasaan, kebudayaan dan lingkungan sosialnya.

2. Pengalaman dan pengamatan. Pengalaman dapat mempengaruhi pengamatan sosial dalam tingkah laku, pengalaman dapat diperoleh dari semua tindakannya dimasa lalu dan dapat dipelajari, melalui belajar orang akan dapat memperoleh pengalaman. Hasil dari pengalaman sosial akan dapat membentuk pandangan terhadap suatu objek.

3. Kepribadian. Kepribadian adalah konfigurasi karakteristik individu dan cara berperilaku yang menentukan perbedaan perilaku dari setiap individu.

4. Konsep diri. Faktor lain yang menentukan kepribadian individu adalah konsep diri. Konsep diri sudah menjadi pendekatan yang dikenal amat luas untuk menggambarkan hubungan antara konsep diri konsumen dengan image merek. Bagaimana individu memandang dirinya akan mempengaruhi minat terhadap suatu objek. Konsep diri sebagai inti dari pola kepribadian akan menentukan perilaku individu dalam menghadapi permasalahan hidupnya, karena konsep diri merupakan frame of reference yang menjadi awal perilaku.

5. Motif. Perilaku individu muncul karena adanya motif kebutuhan untuk merasa aman dan kebutuhan terhadap prestise merupakan beberapa contoh tentang motif. Jika motif seseorang terhadap kebutuhan akan prestise itu besar maka akan membentuk gaya hidup yang cenderung mengarah kepada gaya hidup hedonis.

6. Persepsi. Persepsi adalah proses dimana seseorang memilih, mengatur, dan menginterpretasikan informasi untuk membentuk suatu gambar yang berarti mengenai dunia.

Gaya hidup adalah pola hidup seseorang di dunia yang diekspresikan dalam aktivitas, minat, dan opininya. Gaya hidup menggambarkan "keseluruhan diri seseorang" yang berinteraksi dengan lingkungannya. Pemasar mencari hubungan antara produknya dengan kelompok gaya hidup konsumen. Contohnya, perusahaan penghasil komputer mungkin menemukan bahwa sebagian besar pembeli komputer berorientasi pada pencapaian prestasi. Dengan demikian, pemasar dapat dengan lebih jelas mengarahkan mereknya ke gaya hidup orang yang berprestasi. Merek merupakan ciri-ciri produk yang penting dan dapat mempengaruhi kegiatan-kegiatan pemasaran dari sebuah pemasaran. Pada hakekatnya merek mengidentifikasikan penjual atau pembuat. Merek dapat berupa nama, merek dagang, logo atau simbol lainnya. Agar dapat memberikan sebuah gambaran yang jelas mengenai pengertian merek ini maka penulis mengemukakan merek dari beberapa ahli.

Setiap perusahaan tentu menginginkan merek yang dipakai oleh produknya menjadi merek pilihan konsumen sehingga akan memberikan dukungan yang besar bagi keberhasilan produk tersebut di pasaran. Nama merek yang baik dapat membantu popularitas merek, nama merek dapat menceritakan sesuatu yang penting mengenai perusahaan atau produknya.

Perusahaan yang bersaing di pasar internasional menghadapi masalah khusus dalam memilih nama merek. Suatu nama yang menyandang citra yang positif di satu bahasa bisa tidak berarti apa-apa di lain negara atau mengandung arti yang lebih buruk tanpa bermaksud untuk itu. Sebuah merek yang baik memiliki karakteristik-karakteristik diatas 
meskipun pada kenyataannya tidak semua karakteristik itu dapat terpenuhi tetapi bagaimanapun perusahaan dalam menentukan merek bagi produk-produknya harus berusaha kearah itu.

Citra merek yaitu kepercayaan yang dimiliki konsumen terhadap suatu merek pada produk tertentu dan kepercayaan ini tercipta berkat strategi pemasaran yang diterapkan perusahaan terhadap produk yang dihasilkannya.

Menurut pendapat Belch, George.E \& Michael A. Belch, (2003) citra merek (brand image) adalah bagaimana konsumen dan yang lainnya memahami atau menerima suatu merek". Maksudnya yaitu citra merek merupakan persepsi yang ada di benak konsumen dan yang lainnya terhadap suatu merek.

Kotler (2005:404) berpendapat bahwa citra merek(brand image) adalah. "The set of held about a particular brand is known as the brand image" . Artinya Citra merek adalah sekumpulan nilai mengenai merek-merek. Dikenalnya suatu merek (brand recognition) berarti pelanggan mengingat merek tersebut, hal ini merupakan keuntungan besar jika terdapat banyak merek yang "tidak berarti" di pasaran bahkan meskipun konsumen tidak dapat mengingat merek itu tanpa bantuan. Citra (image) konsumen tentang merek adalah penting untuk strategi pemasaran perusahaan, suatu citra dapat di buat untuk beberapa manfaat yaitu: (1) Citra dapat di buat sebagai tujuan (goal) di dalam strategi pemasaran; (2) Citra dapat di pakai sebagai suatu dasar untuk bersaing dengan merek-merek lain dari produk sejenis; (3) Citra merek juga dapat membantu memperbaharui penjualan suatu merek; (4) Citra merek dapat di pergunakan untuk mengevaluasi efektifitas dari strategi pemasaran; (5) Citra merek dapat di hasilkan dari faktor-faktor lain di luar usaha-usaha strategi pemasaran.

Menurut Prasetijo, Ristiyanti dan Ihalauw John, (2005: 35) Tahap loyalitas tersebut dapat dijelaskan sebagai berikut:

1. First Time Customers. Yaitu membeli untuk yang pertama kalinya. Mereka masih tergolong konsumen yang baru.

2. Repeat Customers. Yaitu konsumen yang telah melakukan pembelian / menggunakan suatu jasa sebanyak dua, tiga kali atau lebih. Mereka adalah yang melakukan pembelian atas produk yang sama sebanyak dua kali atau membeli dua macam produk yang berbeda dalam dua kesempatan yang berbeda pula.

3. Clients. Clients membeli semua barang/ jasa yang ditawarkan, yang mereka butuhkan. Mereka membeli secara teratur, hubungan dengan jenis konsumen ini sudah kuat dan berlangsung lama yang membuat mereka tidak terpengaruh oleh tarikan persaingan produk lain.

4. Advocates. Seperti layaknya klien, advocates membeli seluruh barang / jasa yang ditawarkan yang ia butuhkan serta melakukan pembelian secara teratur. Sebagai tambahan, mereka mendorong teman-teman mereka yang lain agar membeli barang / jasa tersebut. Ia membicarakan tentang barang / jasa tersebut, dan membawa konsumen untuk perusahaan tersebut.

5. Partners. Konsumen pada tingkat ini adalah yang merasakan saling merasakan saling ketergantungan dalam aktivitas bersama untuk saling mendapatkan keuntungan (partners).

Adapun variabel-variabel yang memengaruhi keputusan pembelian dapat dikemukakan sebagai berikut:

1. Kualitas produk. Kepuasan juga tergantung pada akualitas produk dan jasa. Apa sebenarnya kualitas itu?. Berbagai ahli mendefinisikannya sebagai " kecocokan untuk 
digunakan", pemenuhan tuntutan, bebas dari variasi, dan seterusnya. Kita akan menggunakan definisi American Society for Quality Control. Kualitas (quality) adalah total fitur dan karakteristik produk atau jasa yang bergantung pada kemampuannya untuk memuaskan kebutuhan yang dinyatakan atau tersirat. Ini jelas merupakan definisi nyang berpusat pada pelanggan. Kita dapat mengatakan bahwa penjual telah mengantarkan kualitas ketika produk atau jasanya memenuhi atau melebihi ekpektasi pelanggan. Perusahaan yang memuaskan sebagian besar kebutuhan pelanggannya sepanjang waktu disebut perusahaan berkualitas. Lexus memberikan kinerja kualitas yang lebih tinggi dibandingkan Hyundai : mobil Lexus maupun Hyundai lebih mulus, lebih kencang, dan lebih tahan lama. Tetapi kita dapat mengatakan bahwa baik Lexus maupun Hyundai menghantarkan kesesuaian kualitas yang sama, jika semua unit masing-masing menghantarkan kualitas yang diinginkan. (Kotler, 2008 : 143).

2. Harga. Pengusaha perlu memikirkan tentang penetapan harga jual produknya secara tepat karena harga yang tidak tepat akan berakibat tidak menarik para pembeli untuk membeli barang tersebut. Penetapan harga jual barang yang tepat tidak selalu berarti bahwa harga haruslah ditetapkan rendah atau serendah mungkin. Sering di jumpai bahwa apabila harga barang tertentu itu rendah maka banyak konsumen justru tidak senang karena dengan harga yang murah itu maka semua orang dapat memakai barang tersebut. Harga merupakan satu-satunya unsur marketing mix yang menghasilkan penerimaan penjualan, sedangkan unsur lainnya hanya unsur biaya saja. Walaupun penetapan harga merupakan persoalan penting, masih banyak perusahaan yang kurang sempurna dalam menangani permasalahan penetapan harga tersebut. Karena menghasilkan penerimaan penjualan, maka harga memengaruhi tingkat penjualan, tingkat keuntungan, serta share pasar yang dapat dicapai oleh perusahaan. Chandra (2002: 149) mengemukakan bahwa harga adalah jumlah uang (satuan moneter) dan atau aspek lain (non moneter) yang mengandung utilitas/kegunaan tertentu yang diperlukan untuk mendapatkan suatu produk

3. Promosi. Promosi adalah bagian dari bauran pemasaran yang besar peranannya. Promosi merupakan kegatan-kegiatan yang secara aktif dilakukan perusahaan untuk mendorong konsumen membeli produk yang ditawarkan, karena itu promosi dipandang sebagai arus informasi atau persuasi satu arah yang dibuat untuk mengarahkan seseorang atau organisasi agar melakukan pertukaran dalam pemasaran. Kegiatan dalam promosi ini pada umumnya adalah periklanan, personal selling, promosi penjualan, pemasaran langsung, serta hubungan masyarakat dari publisitas. Promosi adalah merupakan kegiatan yang ditujukan untuk memengaruhi konsumen agar mereka dapat menjadi kenal akan produk yang ditawarkan oleh perusahaan kepada mereka dan kemudian mereka menjadi senang lalu membeli produk tersebut. Menurut Tjiptono (2009: 219) mengemukakan bahwa: Promosi adalah suatu bentuk komunikasi pemasaran. Yang dimaksud komunikasi pemasaran adalah aktivitas pemasaran yang berusaha menyebarkan informasi, memengaruhi/membujuk, dan/atau mengingatkan pasar sasaran atas perusahaan dan produknya agar bersedia menerima, membeli, dan loyal pada produk yang ditawarkan perusahaan yang bersangkutan.

4. Distribusi. Saluran distribusi adalah saluran yang digunakan oleh produsen untuk menyalurkan produk sampai ke konsumen atau berbagai aktivitas perusahaan yang mengupayakan agar produk sampai ke tangan konsumen. Saluran distribusi penting, karena barang yang telah dibuat dan harganya sudah ditetapkan itu masih menghadapi masalah, yakni harus disampaikan kepada konsumen. Pada penyalur dapat menjadi alat bagi perusahaan untuk mendapatkan 
umpan balik dari konsumen di pasar. Penentuan jumlah penyalur juga merupakan masalah yang penting untuk dipertimbangkan, dalam kasus-kasus tertentu disesuaikan dengan sifat produk yang ditawarkan. Barang kebutuhan sehari-hari, misalnya membutuhkan banyak penyalur, sedangkan barang-barang berat seperti peralatan industri tidak demikian. Kesalahan dalam menentukan jumlah penyalur akan mendatangkan persoalan baru bagi perusahaan. Bila jumlah penyalur terlalu sedikit menyebabkan penyebaran produk kurang luas, sedangkan jumlah penyalur yang terlalu banyak mengakibatkan pemborosan waktu, perhatian, dan biaya. Karena itu manajer pemasaran perlu berhati-hati dalam menyeleksi dan menentukan jumlah penyalur. Menurut Kasmir dan Jakfar (2003 : 114) mengemukakan bahwa distribusi adalah suatu jaringan dari organisasi dan fungsi-fungsi yang menghubungkan produsen kepada konsumen akhir.

Dalam memahami perilaku konsumen, terdapat banyak pengaruh yang mendasari seseorang dalam mengambil keputusan pembelian suatu produk atau merek. Pada kebanyakan orang, perilaku pembelian konsumen seringkali diawali dan dipengaruhi oleh banyaknya rangsangan (stimuli) dari luar dirinya, baik berupa rangsangan pemasaran maupun rangsangan dari lingkungan yang lain. Rangsangan tersebut kemudian diproses (diolah) dalam diri, sesuai dengan karakteristik pribadinya, sebelum akhirnya diambil keputusan pembelian. Karakteristik pribadi konsumen yang dipergunakan untuk memproses rangsangan tersebut sangat komplek, dan salah satunya adalah motivasi konsumen untuk membeli.

Proses keputusan pembelian suatu produk mengikuti urutan. Peran seseorang (bukan pembeli utama) dalam proses pengambilan keputusan pembelian produk perlu diketahui oleh marketer, karena diantara mereka ini terkadang justru menjadi faktor pendorong yang sangat kuat bagi pengambil keputusan pembelian. Sejumlah orang yang memiliki keterlibatan dalam keputusan pembelian, adalah sebagai berikut: (1) Initiator adalah orang yang pertama kali menyadari adanya kebutuhan yang belum terpenuhi dan berinisiatif mengusulkan untuk membeli produk tertentu; (2) Influencer adalah orang yang sering berperan sebagai pemberi pengaruh yang karena pandangan, nasehat atau pendapatnya memengaruhi keputusan pembelian; (3) Decider adalah orang berperan sebagai pengambil keputusan dalam menentukan apakah produk jadi dibeli, produk apa yang akan dibeli, bagaimana cara membeli, dan dimana produk itu dibeli; (4) Buyer adalah orang yang melakukan pembelian aktual; (5) User adalah orang yang mengkonsumsi atau menggunakan produk yang dibeli.

Marketer harus paham betul peran-peran tersebut dijalankan oleh siapa. Jika dalam satu keluarga peran di atas dimainkan oleh anak, ibu dan lebih dominan ditentukan oleh seorang bapak, maka pesan komunikasi pemasaran harus diarahkan pada yang lebih dominan sebagai pengambil keputusan akhir untuk menentukan pembelian.

Keterlibatan psikologis dalam proses pengambilan keputusan pembelian itu berbedabeda, sesuai dengan sifat keputusan itu sendiri, yaitu pengambilan keputusan yang kompleks, (extended decision making) pengambilan keputusan yang terbatas (limited decision making) dan pengambilan keputusan berdasarkan kebiasaan.

Proses pengambilan keputusan pembelian berakhir pada tahap perilaku purnabeli dimana konsumen merasakan tingkat kepuasan atau ketidakpuasan yang dirasakan akan memengaruhi perilaku berikutnya. Jika konsumen merasa puas, ia akan memperlihatkan peluang yang besar untuk melakukan pembelian ulang atau membeli produk lain pada perusahaan yang sama di masa mendatang, dan cenderung merekomendasikan kepada orang lain. Banyak orang berpendapat bahwa pembeli yang puas merupakan iklan yang terbaik bagi produk. (Hasan 2008, hal. 138-139). 


\section{METODE}

Penelitian mengenai merek dan keputusan pembelian kosmetik pernah dilakukan oleh Khraim (2011) di Arab Saudi dengan menggunakan analisis deskriptif, anova satu arah dan korelasi pearson. Hasil penelitian tersebut menunjukkan bahwa merek memiliki hubungan positif dan signifikan antara faktor loyalitas merek (identitas merek, kualitas produk, harga, desain, promosi, kualitas layanan dan lingkungan toko) dengan loyalitas merek kosmetik yang pada akhirnya berpengaruh terhadap keputusan pembelian konsumen. Tentunya dalam penelitian ini dilakukan pembatasan dengan fokus pada pengaruh gaya hidup dan pengaruh citra merek terhadap keputusan pembelian lipstik pelanggan. Pada penelitian ini pengaruh gaya hidup dan citra merek terhadap keputusan pembelian lipstik dapat dirumuskan dalam paradigma penelitian seperti terlihat gambar 1.1 sebagai berikut:

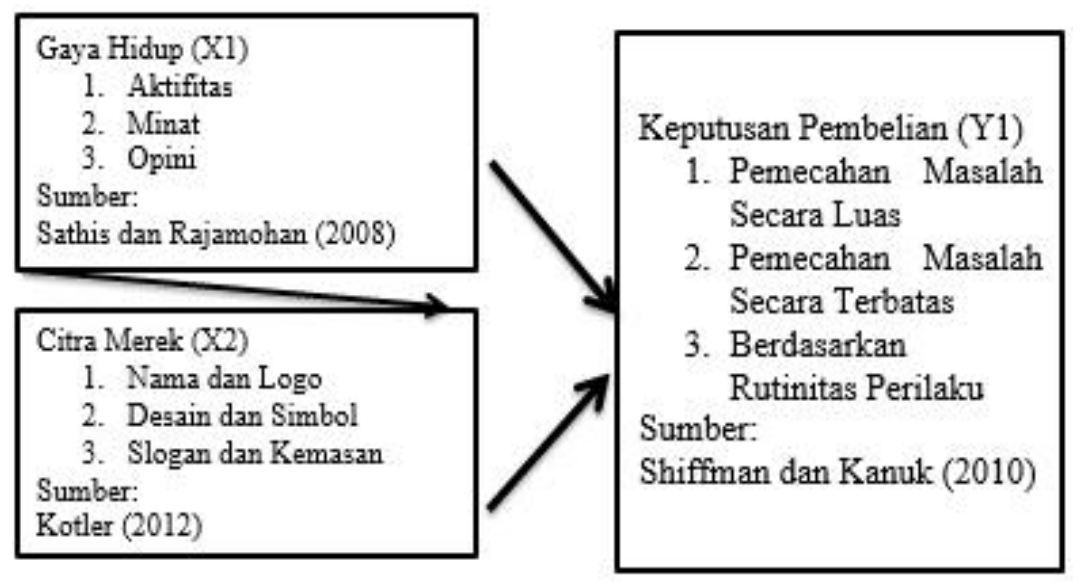

Gambar 1. Paradigma Penelitian

Variabel citra merek diadopsi berdasarkan indikator pada penelitian Sathis dan Rajamohan (2008) meliputi aktivitas, minat, dan opini. Pengukuran tanggapan citra merek mengacu pada pendapat Kotler (2012) meliputi nama, logo, desain, symbol, dan kemasan. Sedangkan keputusan pembelian diadopsi dari pendapat Shiffman dan Kanuk (2010) yang meliputi, pemecahan masalah secara luas, pemecahan masalah secara terbatas, dan tangggapan berdasarkan rutinitas. Model penelitian ini tentunya menjadi dasar analisis dalam mengetahui perilaku pelanggan terkait dengan fenomena keputusan pembelian lipstick berdasarkan gaya hidup melalui citra merek. (Dadhich and K. T. Bhal. 2016).

Berdasarkan metode yang digunakan penelitian ini menggunakan metode deskriptif dan verifikatif. Metode deskriptif merupakan metode dalam meneliti sekelompok individu, objek, system pemikiran atau peristiwa di masa sekarang untuk membuat gambaran atau sistematis faktual dan akurat mengenai fakta-fakta secara hubungan variabel. Menurut Churchill dan Lacobucci (2005) penelitian deskriptif berkaitan dengan proses penentuan frekuensi terjadinya sesuatu atau hubungan antara variabel penelitian. Dalam mempersiapkan kegiatan pengolahan data, telah disusun operasionalisasi variabel yang memuat variabel beserta sub-variabel sebagai serta indicator terkait yang digunakan dalam penelitian ini. Seperti terlampir pada Tabel 2. 
Tabel 2. Operasionalisasi Variabel

\begin{tabular}{clll}
\hline \multicolumn{1}{c}{ Variabel } & \multicolumn{1}{c}{ Subvariabel } & \multicolumn{1}{c}{ Indikator } & skala \\
\hline $\begin{array}{c}\text { Gaya Hidup } \\
(\text { X1 })\end{array}$ & Aktifitas (X1.1) & Aktifitas responden & Ordinal \\
& $\begin{array}{l}\text { Minat (X1.2) } \\
\text { Opini (X1.3) }\end{array}$ & $\begin{array}{l}\text { Minat Responden } \\
\text { Opini Responden }\end{array}$ & $\begin{array}{l}\text { Ordinal } \\
\text { Ordinal } \\
\text { Ordinal }\end{array}$ \\
$\begin{array}{c}\text { Citra Merek } \\
(\text { X2) }\end{array}$ & Nama dan Logo (X2.1) & Nama dan Logo Lipstick & Ordinal \\
& $\begin{array}{l}\text { Desain dan Simbol } \\
\text { (X2.2) }\end{array}$ & Desain dan Simbol Lipstick & Ordinal \\
& Slogan dan Kemasan (X2.3) & Slogan dan Kemasan Lipstick & Ordinal \\
$\begin{array}{c}\text { Keputusan } \\
\text { Pembelian } \\
(\text { Y1 })\end{array}$ & Pemecahan Masalah Secara & $\begin{array}{l}\text { Proses Pemecahan Masalaha } \\
\text { Lecara umum }\end{array}$ & \\
& Pemecahan Masalah Secara & $\begin{array}{l}\text { Proses pemecahan masalaha } \\
\text { kebutuhan secara spesifik }\end{array}$ & Ordinal \\
& $\begin{array}{l}\text { Terbatas (Y1.2) } \\
\text { Berdasarkan Rutinitas Perilaku } \\
\text { K1.3) }\end{array}$ & $\begin{array}{l}\text { Keputusan pembelian } \\
\text { berdasarkan rutinitas perilaku }\end{array}$ & Ordinal \\
& & & \\
\hline
\end{tabular}

\section{HASIL DAN PEMBAHASAN}

Dampak langsung gaya hidup terhadap pembentukan citra merek. Untuk mengetahui dampak antara gaya hidup dengan citra merek dilakukan pengujian statistik dengan metode regresi linier dengan hasil terlampir pada Tabel 3.

Tabel 3. Tabulasi Analisis Regresi Linier

\begin{tabular}{cccccccc}
\hline \multirow{2}{*}{ Model } & \multicolumn{2}{c}{ Unstandardized Coefficients } & $\begin{array}{c}\text { Standardized } \\
\text { Coefficients }\end{array}$ & $\mathrm{t}$ & Sig. & $\begin{array}{c}\text { Adjusted } R \\
\text { Square }\end{array}$ \\
\cline { 2 - 5 } & $\mathrm{B}$ & Std. Error & Beta & & & \\
\hline \multirow{2}{*}{1} & $\begin{array}{c}\text { Constant }) \\
\text { C }\end{array}$ & .829 & .189 & & 4.380 & .000 & \\
& Gaya Hidup & .716 & .065 & .745 & 11.060 & .000 & 0.551 \\
\hline
\end{tabular}

Pada Tabel 3 dapat terlihat bahwa nilai R Square yang dihasilkan sebesar 0.551 yang berarti bahwa gaya hidup memiliki besaran barias kontribusi dalam pembentukan citra merek produk lipstik sebesar 55,1\% sedangkan sisanya sebesar $45,9 \%$ dijelaskan oleh variabel lain yang berada di luar model pengujian data. Sehingga dapat disimpulkan bahwa gaya hidup memiliki dampak cukup signifikan dalam pembentukan citra merek produk lipstik. Sedangkan nilai koefisien beta sebesar 0.745 menunjukan bahwa gaya hidup memiliki dampak langsung yang kuat dalam pembentukan citra merek lipstick pada benak pelanggan. Sehingga dapat dibentuk model dampak langsung antara gaya hidup dan citra merek lipstick seperti terlihat pada Gambar 2.

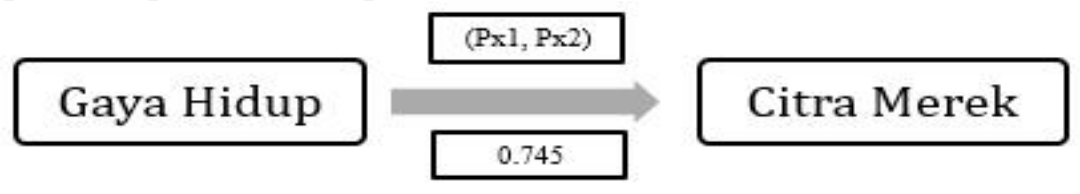

Gambar 2. Model Dampak Langsung Gaya Hidup dan Citra Merek 
Regresi multilinier gaya hidup, citra merk, dan keputusan pembelian. Pengujian statistik menggunakan metode regresi multilinier seperti terlihat pada Tabel 4. Pada Tabel 4 dapat terlihat bahwa nilai $\mathrm{R}$ Square yang dihasilkan sebesar 0.781 yang berarti bahwa gaya hidup dan citra merek memiliki besaran variasi kontribusi dalam pembentukan keputusan pembelianproduk lipstick sebesar $78,1 \%$ sedangkan sisanya sebesar 21,9\% dijelaskan oleh variabel lain yang berada di luar model pengujian data. Sehingga dapat disimpulkan bahwa gaya hidup dan citra merek memiliki dampak signifikan dalam keputusan pembelian produk lipstik.

Besaran nilai koefisien beta gaya hidup pada Tabel 4 sebesar 0.553 menunjukan bahwa citra merek memiliki dampak langsung yang kuat dalam keputusan pembelianproduk lipstick dimata konsumen. Sedangkan hasil pengujian hipotesis kedua diperoleh nilai signifikan sebesar 0.000 dalam pengujian tingkat kesalahan sebesar 0.05 yang berarti bahwa Ho ditolak dan Ha diterima. Sehingga dapat ditarik kesimpulan bahwa gaya hidup berdampak signifikan terhadap keputusan pembelian produk lipstick (Ha Diterima).

Tabel 4. Tabulasi Analisis Regresi Multilinier

\begin{tabular}{cccccccc}
\hline \multirow{2}{*}{ Model } & \multicolumn{2}{c}{$\begin{array}{c}\text { Unstandardized } \\
\text { Coefficients }\end{array}$} & $\begin{array}{c}\text { Standardized } \\
\text { Coefficients }\end{array}$ & $\mathrm{t}$ & Sig. & $\begin{array}{c}\text { Adjusted } \\
\text { R Square }\end{array}$ \\
\cline { 3 - 5 } & & $\mathrm{B}$ & Std. Error & Beta & & & \\
\hline \multirow{2}{*}{1} & (Constant) & .488 & .158 & & 3.089 & .003 & \\
& Gaya Hidup & .844 & .054 & .844 & 15.605 & .000 & \\
& (Constant) & .151 & .152 & & .995 & .322 & 0.781 \\
2 & Gaya Hidup & .552 & .071 & .553 & 7.762 & .000 & \\
& Citra Merek & .407 & .074 & .391 & 5.495 & .000 & \\
\hline
\end{tabular}

Besaran nilai koefisien beta citra merek pada Tabel 4 sebesar 0.391 menunjukan bahwa citra merek memiliki dampak langsung yang cukup kuat dalam keputusan pembelian produk lipstik dimata konsumen. Sedangkan hasil pengujian hipotesis ketiga diperoleh nilai signifikan sebesar 0.000 dalam pengujian tingkat kesalahan sebesar 0.05 yang berarti bahwa Ho ditolak dan Ha diterima. Sehingga dapat disimpulkan bahwa citra merek dapat menjadi variabel intervening antara gaya hidup terhadap keputusan pembelian produk lipstik. (Ha Diterima). Kemudian berdasarkan nilai uji F- Test dan Uji T- Test dapat disimpulkan bahwa gaya hidup dan citra merek berdampak signifikan terhadap keputusan pembelian dikarenakan nilai signifikansi sebesar $0,00<$ alpha 0.05 secara simultan maupun secara parsial karena nilai t-hitung sebesar 7.76 dan 5.5 lebih besar dibandingkan dengan nilai t-tabel dari kedua variabel independen terkait. Berdasarkan grafik normal probability plot seperti yang disajikan pada gambar 3 .

Dari gambar tersebut, terlihat bahwa titik-titik menyebar di sekitar garis diagonal, serta penyebarannya mengikuti arah garis diagonal. Sehingga model regresi layak dipakai untuk prediksi keputusan konsumen dalam melakukan pembelian semen berdasarkan masukan variabel bebasnya. 


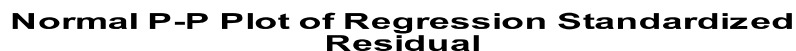

Residual

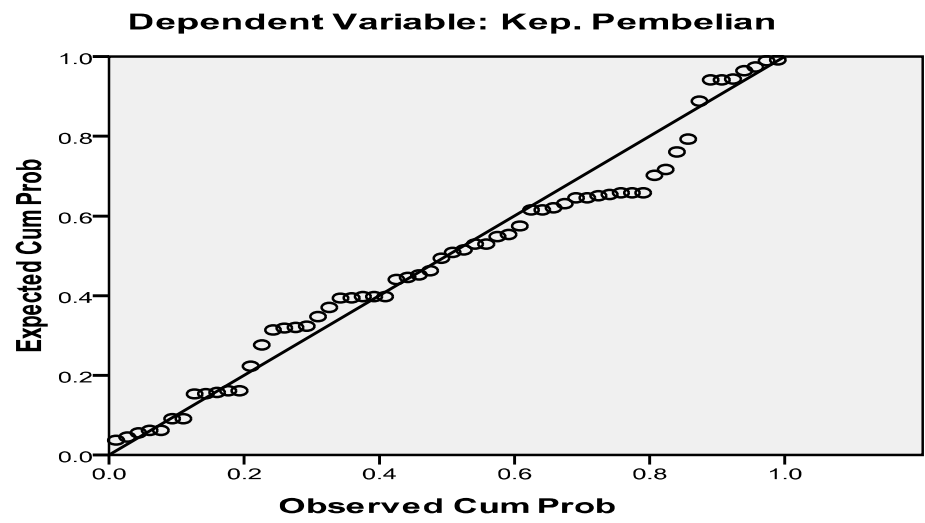

Gambar 3. Normal P-Plot of Regression Standardized Residual

Kalkulasi analisis jalur. Analisis jalur dilakukan untuk menganalisis hubungan sebab akibat yang terjadi pada analis regresi berganda jika variabel bebasnya memengaruhi variabel lainnya baik secara parsial maupun secara simultan. Tahapan pertama dari analisis jalur adalah melakukan penghitungan koefisien jalur sebagai berikut:

$$
\begin{aligned}
& P x y i=\sqrt{\mathbf{1}-R^{2} Y_{X \mathbf{1} x \mathbf{z} x \mathbf{3}}} \\
& P x y i=\sqrt{\mathbf{1}-0.745} \\
& P x y i=\sqrt{0.255} \\
& P x y i=0.505
\end{aligned}
$$

Tahapan kedua didalam analisis jalur adalah mencari nilai pengaruh langsung dan tidak langsung antara variable terkait dengan penghitungan sebagai berikut:

1. Pengaruh Langsung Variabel X1

$$
\begin{aligned}
\mathrm{Y} \leftarrow \mathrm{X} 1 \rightarrow & =\mathrm{Y}: \mathrm{pyx} 1 . \mathrm{pyx} 1 \\
& =0.553 \times 0.553 \\
& =0.2809
\end{aligned}
$$

2. Pengaruh Tidak Langsung Variabel $\mathrm{X} 1$ dan $\mathrm{X} 2$

$$
\begin{aligned}
\mathrm{Y} \leftarrow \mathrm{X} 1 \quad \mathrm{X} 2 \rightarrow \mathrm{Y} & : \text { pyx1.rx1x2.pyx } 2 \\
& =0.553 \times 0.745 \times 0.391 \\
& =0.1611
\end{aligned}
$$

3. Pengaruh Langsung Variabel $\mathrm{X} 2$

$$
\begin{aligned}
\mathrm{Y} \leftarrow \mathrm{X} 2 \rightarrow & =\mathrm{Y}: \mathrm{pyx} 2 . \mathrm{pyx} 2 \\
& =0.391 \times 0.391 \\
& =0.1529
\end{aligned}
$$

Berdasarkan Tabel 5 dapat terlihat bahwa total dampak langsung antara gaya hidup terhadap keputusan pembelian adalah sebesar $28.09 \%$ dan dampak langsung antara citra merek terhadap keputusan pembelian sebesar $15.29 \%$. Sedangkan total pengaruh antara gaya hidup dan citra merek dengan mediasi diantara kedua variabel adalah sebesar $44.2 \%$ dan $31.4 \%$. Pada tabel dapat terlihat bahwa total pengaruh gaya hidup dan citra merek 
terhadap keputusan pembelian adalah sebesar $75.6 \%$ dengan $24.4 \%$ sisanya dipengaruhi oleh variabel lain yang tidak dijelaskan dalam penelitian.

Tabel 5. Tabulasi Analisis Jalur

\begin{tabular}{llcc}
\hline No & \multicolumn{1}{c}{ Deskripsi } & $\%$ & $\%$ \\
\hline 1. & Pengaruh X1 Terhadap Y & 28.09 & \\
2. & Pengaruh X1 Terhadap Y melalui X2 & 16,11 & \\
& Total Pengaruh X1 Terhadap Y & & 44.2 \\
3. & Pengaruh X2 Terhadap Y & 15.29 & \\
4. & Pengaruh X2 Terhadap Y melalui X1 & 16.11 & \\
& Total Pengaruh X2 Terhadap Y & & 31.4 \\
& Total Pengaruh X1 dan X2 Terhadap Y & & 75.6 \\
& Total Pengaruh Variabel lain terhadap Y & 24.4 & 24.4 \\
& Subtotal & 100 & 100 \\
\hline
\end{tabular}

\section{PENUTUP}

Simpulan. Semenjak kemunculannya, lipstick berkembang dari sebuah hal yang tidak umum menjadi sebuah gaya hidup bagi para pelanggannya. Berkembangnya arus mode dan fashion turut membentuk kemunculan berbagai merek yang membalut produk lipstick sebagai sebuah kebutuhan dan gaya hidup bagi para pelangganya. Berdasarkan hasil penelitian dapat dibentuk model kombinasi analisis jalur diantara variable terkait seperti terlihat pada gambar 1.3.

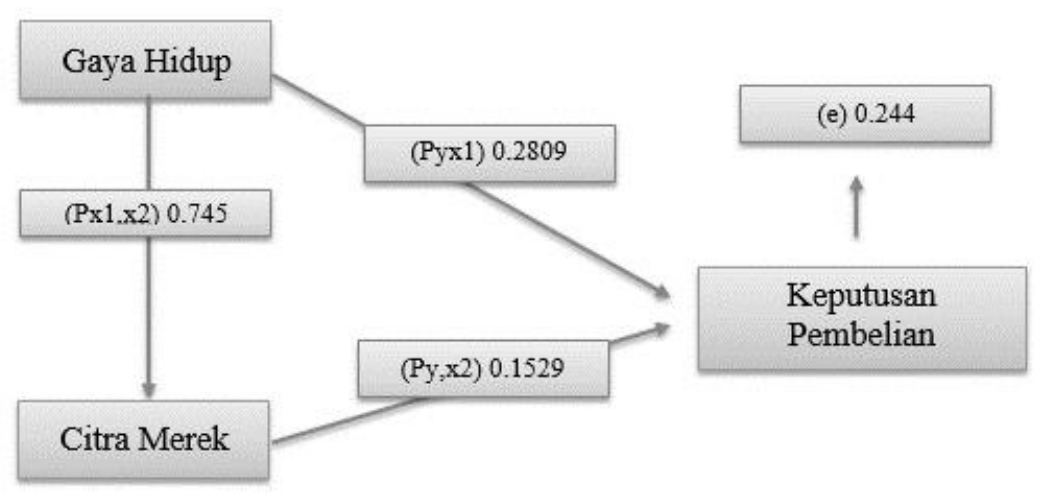

Gambar 4. Model Kombinasi Analisis Jalur Gaya hidup dan Citra Merek Terhadap Keputusan Pembelian Lipstik

Secara singkat, menjadi jelas bahwa keputusan pelanggan dalam melakukan pembelian lipstick dipengaruhi secara langsung maupun tidak langsung. Gaya hidup pelanggan secara signifikan mempengaruhi bagaimana citra sebuah merek terbentuk dalam persepsi pelanggan yang kemudian memperkuat pengaruh keputusan pembelian pelanggan terutama dalam proses pembelian sebuah lipstik. Meski demikian, dampak gaya hidup secara lebih kuat mempengaruhi keputusan pembelian lipstick bagi pelanggan. Hal ini sejalan dengan pendapat Ogilvie dan Ryan (2011) bahwa lipstick dibenak para pelanggannya bukanhanya sebatas sebuah fashion namun telah bermetamorfosis menjadi sebuah gaya hidup. Tentunya hasil ini menjadi penting bagi perusahaan untuk membentuk 
citra merek produk lipstick mereka agar dapat menjadikannya sebuah gaya hidup bagi para pelanggan guna memperoleh hasil yang lebih signifikan terhadap pendapatan perusahaan.

\section{DAFTAR RUJUKAN}

A Rahmat dan Catur Widayati, Christina (2016) "Perceptual Mapping Leadership in Ethnic Regional Perspective (Studies in Six Ethnic Dominant Gorontalo)". International Journal of Economic Perspectives, 10 (2), 171-179.

A Rahmat. (2017) "Clustering in Education" European Research Studies Journal. XX, (3A), 311-324

Amirullah, (2012) Perilaku Konsumen, edisi pertama, cetakan pertama, Penerbit: Graha Ilmu, Yogyakarta.

Barth-Farkas, Faye; Vera, Antonio. (2016) "Power and Transformational Leadership in Public Organizations". International Journal of Leadership in Public Services. 22 (4), 251-266

Bass, B.M. (2017) "From Transactional to Transformational Leadership: Learning to share the vision". Organizational Dynamics, Elsevier. 18 (3).

Belch, George.E \& Michael A. Belch, (2003) Advertising and promotion: An Integrated Marketing Communications perspective, Sixth edition. The McGraw-Hill Companies.

Chandra, Gregorius, (2002) Strategi Dan Program Pemasaran, edisi pertama, cetakan pertama, Penerbit: Andi, Yogjakarta

Dadhich and K. T. Bhal. (2016) "Ethical Leader Behavior and Leader-Member Exchange as Predictors of Subordinate Behaviors", Journal for Decision Makers, 33(4), 194198

Gilbert A. Churchill, Jr Dawn Lacobucci. (2005) Marketing Research Methodological Foundation ninth edition, south western

Hamza Salim Khraim. (2011) "The Influence of product variety on brand perception and choice". International Journal of Marketing Studies, 3 (2), 123-133

Hasan Ali, (2008) Marketing, cetakan pertama, Penerbit: MedPress, Yogyakarta

Hoeffler, Steve and Keller, Kevin Lane, (2003) "The Marketing Advantages of Strong Brands (August 1, 2003)". The Journal of Brand Management, 10 (6), 421-445, August.

Kasmir dan Jakfar, (2003) Studi Kelayakan Bisnis, edisi pertama, cetakan pertama, Penerbit : Prenada Media, Jakarta

Kementrian Perindustrian Republik Indonesia. (2013) Indonesia lahan subur industri kosmetik. $\quad$ http://kemenperin.go.id/artikel/5897/Indonesia-Lahan-Subur-IndustriKosmetik

Kotler, P dan Keller, K.L. (2012) Marketing Management Edisi 14, Global Edition. Pearson Prentice Hall.

Kotler, Philip dan Keller, Kevin Lane, (2008) Manajemen Pemasaran, edisi ketiga belas, jilid dua, Penerbit: Erlangga, Jakarta

Ogilvie, Madeleine. (2011) Lipstick: More than a Fashion Trend. Ecu Publication the Mc Graw-Hill Companies

Prasetijo, Ristiyanti dan Ihalauw John, (2005) Perilaku Konsumen, edisi pertama, Penerbit: Andi, Yogyakarta

Rajamohan \& Sathis, S. (2008) Consumer Behaviour and Lifestyle Marketing, Volume 1 
Rajput, Ansir A. (2012) "Impact of Product Price and Quality on Consumer Buying Behavior: Evidence from Pakistan". Journal Of Contemporary Research in Business, 4 (4), 485-496.

Schiffman, Leon G. dan Leslie Lazar Kanuk. (2010) Consumer Behavior Tenth Edition. Pearson Education.

Tjiptono, Fandy, (2009) Manajemen Jasa, cetakan kedua, edisi kesatu, Penerbit: Erlangga, Jakarta. 